\title{
Upaya Meningkatkan Prestasi Belajar Siswa Kelas VII B SMP Negeri 9 Kota Jambi dalam Operasi Hitung Bilangan Bulat Melalui Pemanfaatan Alat Peraga Garis Bilangan
}

\begin{abstract}
Nurmawati $^{1}$
Abstrak: Operasi hitung bilangan bulat merupakan satu diantara beberapa materi dasar dalam pembelajaran matematika yang pengaplikasiannya digunakan hingga ke perguruan tinggi. Hal ini menunjukkan pentingnya memahami operasi hitung pada bilangan bulat. Penelitian ini bertujuan untuk meningkatkan prestasi belajar siswa pada materi operasi hitung bilangan bulat melalui pemanfaatan alat peraga garis bilangan. Penelitian ini merupakan penelitian tindakan kelas dengan 3 siklus, dimana subjek penelitiannya ialah siswa kelas VII B SMP Negeri 9 Kota Jambi. Hasil penelitian menunjukkan antusiasme siswa dalam mengikuti pembelajaran mulai dari siklus pertama, kedua dan ketiga mengalami peningkatan. Selain itu ketuntasan belajarnya juga mengalami peningkatan, yaitu $23 \%$ pada siklus pertama, $40 \%$ pada siklus kedua dan $88 \%$ pada siklus ketiga. Temuan lain dalam penelitian ini ialah faktor penyebab kesulitan belajar siswa pada pokok bahasan ini antara lain: (1) Siswa tidak paham menjumlahkan bilangan bulat positif dengan bilangan bulat negatif; (2) Siswa tidak paham mengurangkan bilangan bulat positif dengan bilangan bulat negatif dan bilangan bulat negatif dengan bilangan bulat negatif; (3) Siswa tidak paham membagi bilangan bulat positif dengan bilangan bulat negatif dan bilangan bulat negatif dengan bilangan bulat negatif.
\end{abstract}

Kata Kunci: Prestasi Belajar, Bilangan Bulat, Garis Bilangan

\begin{abstract}
An integer counting operation is one of several basic materials in mathematics learning whose applications are used up to college. This shows the importance of understanding counting operations on integers. This study aims to improve student learning achievement in integer counting operation material through the use of number line props. This research is a classroom action research with 3 cycles, in which the research subjects are students of class VII B SMP Negeri 9 Jambi City. The results of the study showed the enthusiasm of students in participating in the learning starting from the first, second and third cycles had increased. In addition, the mastery of learning also increased, namely $23 \%$ in the first cycle, $40 \%$ in the second cycle and $88 \%$ in the third cycle. Other findings in this study are the factors causing student learning difficulties on this subject, among others: (1) Students do not understand adding positive integers with negative integers; (2) Students do not understand subtracting positive integers with negative integers and negative integers with negative integers; (3) Students do not understand dividing positive integers with negative integers and negative integers with negative integers.
\end{abstract}

Keywords: Learning Achievement, Integers, Number Line

\section{PENDAHULUAN}

Undang-Undang Nomor 20 tahun 2003 tentang Sistem Pendidikan Nasional, disebutkan bahwa Pendidikan Nasional bertujuan mencerdaskan kehidupan bangsa dan mengembangkan manusia Indonesia seutuhnya. Yaitu manusia yang beriman dan bertaqwa kepada Tuhan Yang Maha Esa dan berbudi pekerti yang luhur, memiliki pengetahuan dan ketrampilan, kesehatan jasmani dan rohani. Kepribadian yang mantap dan mandiri serta rasa tanggung jawab kemasyarakatan dan kebangsaan. Untuk mencapai tujuan tersebut diperlukan upaya yang terencana, terarah, terpadu, dan berkesinambungan. Salah satu upaya tersebut adalah tersedianya prasarana dan sarana yang memadai.

Tujuh puluh persen penduduk Indonesia bermukim di pedesaan dan bermata pencaharian sebagai petani. Itu pun tidak memiliki lahan sendiri. Sebagian besar adalah sebagai buruh tani atau penggarap. Demikian juga latar belakang keadaan sosial, ekonomi, dan budaya siswa SMP Negeri 9 Kota Jambi. Hal inilah yang sangat berpengaruh terhadap kualitas peserta didik. Mereka yang berprestasi lebih menjatuhkan pilihannya ke sekolah negeri unggulan. Sehingga SMP Negeri 9 Kota Jambi lebih banyak menjadi tempat belajar bagi anak-anak yang bermasalah. Mereka umumnya memiliki masalah di bidang ekonomi, prestasi belajar, dan perilaku sosial. Kondisi sosial ekonomi para tua/wali jelas sangat berpengaruh terhadap kondisi siswa di sekolah. Minat belajar siswa menjadi rendah. Hal ini karena tidak ada kontrol dari orang tua/wali. Pengawasan orang tua/wali masih sebatas keberangkatan putra-putrinya ke sekolah. Tetapi pengawasan

\footnotetext{
${ }^{1}$ SMP Negeri 9 Kota Jambi, Indonesia
} 
terhadap aktivitas belajar anak di sekolah maupun di rumah masih rendah. Misalnya, para orang tua/wali tidak mengontrol buku catatan anaknya, dan tidak mengingatkan untuk belajar saat di rumah. Dari situasi seperti inilah kerapkali muncul siswa bermasalah.

Hampir setiap hari selalu saja ada siswa yang datang terlambat ke sekolah. Tiap kali diberi tugas rumah selalu dijumpai siswa yang tidak mengerjakan. Tentu perilaku siswa tersebut sedikit banyak akan mengganggu proses belajar mengajar yang sedang berlangsung. Hal ini lebih disebabkan oleh peran orang tua siswa yang kurang respon terhadap pendidikan yang sedang dijalani oleh putra-putrinya. Akibatnya prestasi belajar siswa tidak sesuai dengan indikator kurikulum. Kesimpulannya, kondisi sosial ekonomi masyarakat akan berbanding lurus terhadap prestasi akademik yang dicapai oleh putra-putrinya. Bukti dari semuanya ini adalah daya serap siswa terhadap mata pelajaran matematika kurang memuaskan.

Memang selama ini ada anggapan jika matematika merupakan pelajaran yang sangat sulit. Apalagi dengan gaya dan penampilan guru mapel yang bersangkutan sering terlihat angker, sehingga menjadikan matematika sebagai momok bagi siswa. Salah satu pokok bahasan yang dianggap menjadi masalah bagi siswa kelas VII B SMP Negeri 9 Kota Jambi adalah Pokok Bahasan Bilangan Bulat. Pada Pokok Bahasan ini ada 6 sub Pokok Bahasan, yaitu: Bilangan Bulat dan Lambangnya, Penjumlahan, Pengurangan, Perkalian, Pembagian, dan Operasi Hitung pada Bentuk Aljabar. Peneliti menganggap pembelajaran pada pokok bahasan ini bermasalah karena nilai rata-rata dari ulangan harian hanya mencapai 5,8. Padahal dalam sistem penilaian Kurikulum Berbasis Kompetensi siswa dianggap tuntas belajar apabila mendapat nilai minimal 7,5 untuk ranah kognitif.

Berdasarkan uraian di atas, peneliti menganggap bahwa pembelajaran Pokok bahasan Bilangan Bulat penting untuk diteliti. Mengingat aplikasi dari Bilangan Bulat tidak hanya ditingkat SMP saja tetapi hingga Perguruan Tinggi masih tetap digunakan. Harapannya setelah diteliti maka dapat meningkatkan nilai rata-rata siswa pada Pokok bahasan tersebut. Dan tentunya ke depan dapat dijadikan sebagaiu model pembelajaran yang efektif. Pada penelitian tindakan kelas ini peneliti mangambil judul Upaya Meningkatkan Prestasi Belajar Siswa Kelas VII B SMP Negeri 9 Kota Jambi dalam Operasi Hitung Bilangan Bulat Melalui Pemanfaatan Alat Peraga Garis Bilangan. Diharapkan dengan adanya alat peraga berupa garis bilangan akan mudah menerima konsep operasi hitung bilangan bulat. Tentunya alat peraga tersebut di desain semenarik mungkin agar selain mengandung nilai edukatif juga terdapat unsur rekreatif.

Ada 3 alasan kenapa peneliti melakukan penelitian terhadap pembelajaran operasi hitung bilangan bulat. Pertama, nilai ulangan harian untuk pokok bahasan bilangan bulat belum memenuhi syarat untuk dikatakan tuntas belajar. Kedua, belum ditemukan model pembelajaran yang efektif untuk materi tersebut. Ketiga, mencari solusi agar siswa dapat menguasai materi tersebut dengan baik. Meskipun dalam pokok bahasan bilangan bulat terdapat enam sub pokok bahasan, namun karena keterbatasan tempat, waktu, dan biaya sehingga penulis hanya mengambil satu sub pokok bahasan, yaitu penjumlahan, pengurangan, perkalian, dan pembagian bilangan bulat.

Penelitian ini bertujuan untuk meningkatkan prestasi belajar siswa kelas VII B SMP Negeri 9 Kota Jambi dalam operasi hitung bilangan bulat melalui pemanfaatan alat peraga garis bilangan. Adapun kontribusi yang diharapkan dari penelitian ini antara lain: (1) Memudahkan siswa dalam memahami konsep operasi hitung bilangan dengan memanfaatkan alat peraga garis bilangan; (2) Menjadikan guru lebih mandiri serta memiliki keberanian untuk menyusun model pembelajaran sendiri.; (3) Menjadi salah satu referensi bagi sekolah dalam merespon permasalahan pembelajaran secara aktual.

\section{Landasan Teori \\ Pengertian Belajar}

Belajar merupakan kebutuhan setiap orang. Siapapun pasti menjalani dan mengalami proses belajar. Hampir semua pengetahuan, kecakapan, keterampilan, kegemaran, dan sikap seseorang terbentuk dan berkembang melalui proses belajar. Proses belajar tidak hanya terjadi di dalam suatu lembaga pendidikan, akan tetapi dapat berlangsung di luar lembaga pendidikan. Mengingat hal yang demikian, maka wajarlah apabila pengertian belajar menurut beberapa tokoh tidaklah sama meskipun secara garis besar tidak jauh berbeda. Berikut ini peneliti kemukakan beberapa pendapat mengenai pengertian belajar sebagaimana dikutip oleh Kuswandi (2001:20): 
1. Belajar adalah usaha dalam menuntut ilmu atau mencari ilmu.

2. Menurut Higrard dan Bower belajar itu berhubungan dengan perubahan tingkah laku seseorang dalam situasi tertentu, situasi tersebut dialami oleh orang itu secara berulang ulang. Perubahan tingkah laku itu didasarkan pada situasi-situasi sesaat yang dialami seseorang.

3. Menurut Robert M Gagne belajar adalah berubahnya perbuatan dan isi ingatan seseorang setelah ia mengalami dan terpengaruh oleh situasi suatu stimulus.

4. Menurut Lindgren telah terjadi apabila terlihat adanya beberapa perubahan dalam tingkah laku sebagai hasil latihan atau pengalaman dalam interaksi dengan lingkungannya. Perubahan yang terjadi akibat belajar disebabkan karena seseorang telah menghadapi suatu situasi secara berulang-ulang.

Berpijak pada beberapa pengertian di atas, dapat disimpulkan bahwa belajar pada hakikatnya adalah suatu kegiatan yang dilakukan secara sadar dengan kemauan seseorang untuk menghasilkan perubahan tingkah laku pada diri sendiri dari pengetahuan baru dan ketrampilan baru.

\section{Pengertian Prestasi Belajar}

Pengertian belajar telah diterangkan peneliti di atas. Adapun pengertian prestasi adalah hasil yang telah dicapai seseorang berupa kemampuan pengetahuan dan pemahaman, ketrampilan serta sikap setelah proses belajar. Sedangkan menurut Munandar (dalam Sugeng Hariyadi,1987:21) perwujudan dari bakat dan kemampuan adalah prestasi. Bakat dan kemampuan menentukan prestasi seseorang. Orang yang memiliki bakat matematika, dapat diperkirakan atau diharapkan untuk mencapai prestasi menonjol di bidang matematika, dan prestasi yang menonjol di suatu bidang dapat merupakan cerminan dari bakat yang dimiliki untuk bidang tersebut. Tetapi karena bakat masih merupakan potensi, orang yang berbakat belum tentu mampu mencapai prestasi yang tinggi dalam bidangnya.

Demikian halnya orang yang menunjukkan prestasi menonjol dalam bidang tertentu, selalu merupakan perwujudan dari bakat khusus yang dimiliki. Hanya bakat khusus yang memperoleh kesempatan untuk berkembang sejak dini melalui latihan, di dukung oleh fasilitas, dan disertai minat yang tinggi sehingga akan terealisasikan dalam kemampuan dan menghasilkan prestasi unggul.

Dengan demikian prestasi belajar dapat diartikan kemampuan dan bakat seseorang yang menonjol di bidang tertentu. Sehingga dipereoleh perubahan dalam berinteraksi dengan lingkungannya. Maka akan diperoleh pengetahuan baru yaitu penguasaan, penggunaan, maupun penilaian mengenai sikap dan kecakapan yang merupakan perilaku dari berbagai keadaan sebelumnya.

\section{Faktor-Faktor yang Mempengaruhi Belajar}

Perkembangan budaya yang sangat pesat mempengaruhi perkembangan masyarakat secara komprehenship. Perkembangan dalam pendidikan dan sosial ekonomi memunculkan pandangan baru tentang persekolahan. Pandangan dalam dunia pendidikan ini antara lain adalah penyediaan kesempatan untuk berkembang secara optimal bagi setiap siswa dan perlunya pembinaan perseorangan agar perkembangannya mencapai harapan yang diinginkan.

Kenyataan menunjukkan bahwa semakin majunya kebudayaan dan semakin berkembangnya masyarakat memberikan dampak semakin banyaknya masalah yang harus dihadapi. Akibatnya adalah bertambah banyak orang yang dihinggapi masalah kesehatan mental. Kondisi ini mendorong kebutuhan akan bimbingan pendidikan guna membantu para siswa dalam memecahkan masalah moral sosial dan pendidikan.

Di sekolah di samping banyak siswa yang berhasil secara gemilang dalam belajar, sering pula dijumpai adanya siswa yang gagal, seperti angka raportnya rendah, tidak naik kelas, tidak lulus ujian akhir dan sebagainya. Secara umum siswa-siswa seperti itu dipandang mengalami masalah belajar. Menurut Walgito (1995:120) faktor-faktor yang mempengaruhi proses dan hasil belajar adalah sebagai berikut.

\section{Faktor Internal}

a. Keterlambatan akademik

Keadaan siswa yang diperkirakan memiliki inteligensi cukup tinggi tetapi tidak dapat memanfaatkannya.

b. Ketercepatan belajar

Keadaan siswa yang memiliki bakat akademik sangat tinggi, tetapi masih memerlukan tugas-tugas khusus untuk memenuhi kebutuhan dan belajarnya yang amat tinggi. 
c. Ketercepatan belajar

Keadaan siswa yang memilki bakat akademik kurang memadai, dan perlu mendapatkan pendidikan atau pengajaran khusus.

d. Kurang motivasi belajar

Keadaan siswa yang memiliki yang kurang semangat dalam belajar.

e. Bersikap dan berkebiasaan buruk dalam belajar

Kondisi siswa yang kegiatan belajarnya sehari-hari antagonistik dengan yang seharusnya, seperti suka menunda- nunda tugas, mengulur-ngulur waktu, membenci guru, tidak mau bertanya untuk hal-hal yang tidak diketahui dan sebagainya.

\section{Faktor Eksternal}

a. Lingkungan keluarga, seperti ketidakharmonisan hubungan antara ayah dan ibu serta kesulitan ekonomi keluarga.

b. Lingkungan masyarakat, seperti wilayah perkampungan kumuh, dan teman sepermainan yang nakal.

c. Lingkungan sekolah, seperti kondisi dan letak gedung yang kurang nyaman, kondisi guru dan alatalat belajar yang berkualitas rendah.

d. Kebijakan penilaian tentang hasil belajar merupakan puncak harapan siswa. Secara kejiwaan terpengaruh hasil belajar, oleh karena itu guru harus aktif dan bijaksana dalam penilaian.

\section{Bilangan Bulat}

\section{Pengertian Bilangan Bulat}

Cholik, Sugijono, D.Subroto (2000:37) menyebutkan bahwa bilangan yang pertama kali dikenal dan digunakan oleh manusia dalam kebutuhannya untuk membilang adalah bilangan $1,2,3,4,5, \ldots$ yang disebut bilangan asli dan dilambangkan dengan A. Dalam perkembangan sistem bilangan, bilangan asli saja yang dapat digunakan untuk menyatakan banyak anggota himpunan kosong yaitu bilangan nol (nol). Selain itu dengan bilangan nol maka dapat dibedakan bilangan-bilangan dengan sistem numerasi nilai tempat pada bilangan Hindu-Arab, misalnya 32, 46, dan 250. Gabungan antara himpunan bilangan asli dengan bilangan 0 disebut himpunan bilangan cacah, yang sering digunakan banyak anggota suatu himpunan.

Himpunan bilangan cacah dilambangkan dengan $\mathrm{C}$. Ternyata himpunan bilangan cacah dan himpunan bilangan asli belum mampu mencatat semua kejadian yang ada, misalnya untuk mencatat suhu- suhu yang sangat dingin seperti di Jepang, puncak pegunungan Himalaya, Bosnia, di daerah kutub dan lain sebagainya, yang suhunya selalu di bawah nol derajat Celcius. Untuk keperluan tersebut akhirnya dipergunakan bilangan tersendiri yang disebut bilangan negatif. Jadi himpunan bilangan bulat adalah merupakan gabungan dari bilangan asli, bilangan cacah, dan bilangan negatif. Bilangan bulat dilambangkan dengan huruf $\mathrm{B}$. Apabila ditulis anggota-anggotanya adalah $\mathrm{B}=\{\ldots,-3,-2,-1,0,1,2,3, \ldots\}$.

\section{Operasi Hitung Bilangan Bulat}
a. Penjumlahan Bilangan Bulat
b. Pengurangan Bilangan Bulat
c. Perkalian Bilangan Bulat
d. Pembagian Bilangan Bulat

\section{Alat Peraga}

Menurut Sadiman (2001:175) dikatakan proses belajar mengajar pada hakekatnya adalah proses komunikasi, yaitu proses penyampaian pesan dari sumber pesan melalui saluran/media tertentu kepada penerima pesan dan penerima pesan adalah komponen- komponen proses komunikasi. Pesan yang akan disampaikan adalah isi ajaran/didikan yang ada dalam kurikulum, sumber pesannya bisa berupa guru, orang lain, siswa ataupun penulis buku atau skenario. Salurannya media pendidikan, dan penerima pesannya adalah siswa atau juga guru.

Sedangkan menurut Darhim (dalam Sugiarto dan Isti Hidayah 2004:3) menuturkan bahwa, pada hakekatnya pembelajaran (belajar dan mengajar) merupakan proses komunikasi antara guru dan siswa. Sebagai komunikan pada proses pembelajaran di atas adalah siswa, sedangkan komunikatornya adalah guru dan siswa. Jika sekelompok siswa menjadi komunikator terhadap siswa lainnya dan guru sebagai fasilitator, maka akan terjadi proses interaksi dengan kadar pembelajaran yang tinggi. 
Seorang guru harus menyadari bahwa proses komunikasi tidak selalu dapat berjalan dengan lancar, bahkan komunikasi dapat menimbulkan kebingungan, salah pengertian, atau bahkan salah konsep. Kesalahan komunikasi bagi seorang guru akan dirasakan oleh siswanya sebagai penghambat pembelajaran. Kesalahan komunikasi dalam pembelajaran dapat terjadi karena factor (1) Siswa; (2) Guru; (3) Guru dan siswa.

Komunikasi yang efektif banyak ditentukan juga pada keefektifan penerima (komunikan). Feed back (mental maupun fisik) dari komunikan dapat dijadikan sebagai alat kontrol komunikator untuk mengevaluasi diri. Sehingga memungkinkan komunikator melakukan perbaikan-perbaikan cara komunikasi yang telah dilakukan.

Untuk menghindari terjadinya kemungkinan-kemungkinan terjadinya salah komunikasi maka diperlukan alat bantu (sarana) yang dapat membantu proses komunikasi. Sarana tersebut selanjutnya disebut media.

Beberapa telah menjelaskan pengertian tentang media pengajaran dalam pernyataan yang tidak sama, pengertian- pengertian tersebut adalah:

1) Menurut Darhim: Alat peraga yang penggunaannya diintegrasikan dengan tujuan dan isi pengajaran yang telah tertuang dalam Garis-garis Besar Program Pengajaran (GBPP) dan bertujuan untuk meningkatkan kualitas pembelajaran.

2) Menurut Anderson: Alat peraga sebagai media atau perlengkapan yang digunakan untuk membantu guru mengajar.

3) Menurut Briggs: Media pembelajaran meliputi objek (benda nyata), model, suara langsung, rekaman radio, pembelajaran terprogram, televisi, dan slide.

4) Menurut Tim PKG: Alat peraga merupakan benda-benda kongkret sebagai model dan ide-ide matematika untuk penerapannya.

\section{METODE PENELITIAN}

\section{Pendekatan dan Jenis Penelitian}

Jenis penelitian ini adalah Penelitian Tindakan Kelas (classroom action research). PTK ditandai dengan adanya suatu tindakan dalam upaya memperbaiki proses belajar mengajar di kelas. PTK didefenisikan sebagai suatu bentuk penelitian yang bersifat reflektif dengan melakukan tindakantindakan tertentu, agar dapat memperbaiki dan meningkatkan praktek-praktek pembelajaran di kelas secara lebih profesional. Penelitian tindakan kelas merupakan salah satu media yang dapat digunakan oleh guru untuk memahami apa yang terjadi di kelas dan untuk meningkatkan ke arah perbaikan secara professional.

\section{Subjek Penelitian}

Subjek penelitian adalah kelas VII B semester I di SMP Negeri 9 Kota Jambi Kecamatan Jambi Timur Kota Jambi tahun pelajaran 2016/2017. Jumlah siswa kelas VII B pada tahun ajaran ini, adalah 43 siswa yang terdiri dari 21 siswa laki-laki dan 22 siswa perempuan.

\section{Prosedur Penelitian}

Prosedur dalam penelitian ini merupakan siklus kegiatan yang terdiri dari tiga siklus dan masingmasing siklus meliputi perencanaan (planning), pelaksanaan tindakan (action), observasi (observation) dan reflection. Alat peraga garis bilangan sebagai upaya pemecahan masalah dalam mengoperasikan bilangan bulat meliputi sejumlah rencana tindakan yang direncanakan sebanyak tiga siklus.

\section{Sumber Data}

Sumber data dalam penelitian ini adalah sebagai berikut: (1) Hasil tes formatif; (2) Interview guru dengan siswa; (3) Literatur; (4) Angket.

\section{Teknik Pengumpulan Data}

Teknik pengumpulan data dalam penelitian ini sebagai berikut: 
1. Tes formatif digunakan untuk mengukur prestasi siswa dalam pembelajaran matematika pokok bahasan operasi hitung bilangan bulat.

2. Tes formatif pertama dilaksanakan pada akhir siklus 1 .

3. Tes formatif kedua dilaksanakan pada akhir siklus 2 .

4. Tes formatif ketiga dilaksanakan pada akhir siklus 3.

5. Membuat lembar pengamatan (observasi).

6. Membuat soal-soal tes formatif.

\section{Materi Tes}

Materi tes disesuaikan dengan materi eksperimen meliputi sub pokok bahasan.

1. Bilangan Bulat dan Lambangnya

2. Penjumlahan

3. Pengurangan

4. Perkalian

5. Pembagian

6. Operasi Hitung pada Bentuk Aljabar

\section{Tolak Ukur Keberhasilan}

Siswa dapat meningkatkan kemampuan dalam menyelesaikan soal-soal latihan dalam mengoperasikan bilangan bulat dengan pemanfaatan alat peraga garis bilangan. Kemampuan siswa dapat dikatakan meningkat dalam penelitian ini apabila hasil rata-rata tes akhir siklus 3 adalah 7,5.

\section{HASIL DAN PEMBAHASAN \\ Hasil Penelitian Selama Tiga Siklus}

Tabel 1.

Partisipasi siswa dalam proses belajar mengajar

\begin{tabular}{ccccccc}
\hline Partisipasi & Siklus I & \multicolumn{2}{c}{ Siklus II } & \multicolumn{2}{c}{ Siklus III } \\
Siswa & Jumlah Siswa & Persentase & Jumlah Siswa & Persentase & Jumlah Siswa & Persentase \\
\hline Acuh & 12 & $30 \%$ & 8 & $20 \%$ & 2 & $5 \%$ \\
Sedang & 16 & $40 \%$ & 13 & $32,5 \%$ & 5 & $12,5 \%$ \\
Aktif & 12 & $30 \%$ & 19 & $47, \%$ & 33 & $82,5 \%$ \\
Jumlah & 40 & $100 \%$ & 40 & $100 \%$ & 40 & $100 \%$ \\
\hline
\end{tabular}

Tabel 2.

Partisipasi siswa dalam menyerap materi pelajaran

\begin{tabular}{|c|c|c|c|c|c|c|}
\hline \multirow[b]{2}{*}{ Prestasi Siswa } & \multicolumn{2}{|c|}{ Siklus I } & \multicolumn{2}{|c|}{ Siklus II } & \multicolumn{2}{|c|}{ Siklus III } \\
\hline & Jumlah Siswa & Persentase & Jumlah Siswa & Persentase & Jumlah Siswa & Persentase \\
\hline Nilai 60 & 23 & $77 \%$ & 16 & $40 \%$ & 6 & $12 \%$ \\
\hline \multirow[t]{2}{*}{ Nilai $>60$} & 17 & $23 \%$ & 24 & $60 \%$ & 34 & $88 \%$ \\
\hline & \multicolumn{2}{|c|}{ Siklus I } & \multicolumn{2}{|c|}{ Siklus II } & \multicolumn{2}{|c|}{ Siklus III } \\
\hline Partisipasi Siswa & Jumlah Siswa & Persentase & Jumlah Siswa & Persentase & Jumlah Siswa & Persentase \\
\hline Tuntas Belajar & 17 & $23 \%$ & 24 & $40 \%$ & 34 & $88 \%$ \\
\hline & 23 & $77 \%$ & 16 & $60 \%$ & 6 & $12 \%$ \\
\hline Nilai Rata-rata & \multicolumn{2}{|c|}{$2460: 40=61,5 \%$} & \multicolumn{2}{|c|}{$2650: 40=66,26$} & \multicolumn{2}{|c|}{$2900: 40=72,5$} \\
\hline Taraf Serap & \multicolumn{2}{|c|}{$61,5 \times 100 \%=61,5 \%$} & \multicolumn{2}{|c|}{$66,25 \times 100 \%=66,25 \%$} & \multicolumn{2}{|c|}{$72,5 \times 100 \%=72,5 \%$} \\
\hline
\end{tabular}

Tabel 3.

Kemampuan Siswa dalam Memahami soal

\begin{tabular}{|c|c|c|c|}
\hline Tingkat Pemahaman Soal Pembagian & Siklus I & Siklus II & Siklus III \\
\hline $\begin{array}{l}\text { 1. Siswa tidak dapat menjumlahkan bilangan bulat positif dengan bilangan } \\
\text { bulat negatif. }\end{array}$ & $52 \%$ & $27 \%$ & $10 \%$ \\
\hline $\begin{array}{l}\text { 2. Siswa tidak dapat mengalikan bilangan bulat positif dengan bilangan } \\
\text { bulat negatif. }\end{array}$ & $48 \%$ & $21 \%$ & $12 \%$ \\
\hline $\begin{array}{l}\text { 3. Siswa tidak dapat membagi bilangan bulat positif dengan bilangan bulat } \\
\text { negatif. }\end{array}$ & $45 \%$ & $18 \%$ & 11 \\
\hline
\end{tabular}


Tabel 4.

Pengamatan KBM oleh guru lain selama dua siklus

\begin{tabular}{lccc}
\hline \multicolumn{1}{c}{ Item yang diamati } & Siklus I & Siklus II & Siklus III \\
\hline 1. Pendahuluan & $\mathrm{C}$ & $\mathrm{B}$ & $\mathrm{A}$ \\
2. Pengembangan & $\mathrm{C}$ & $\mathrm{B}$ & $\mathrm{B}$ \\
3. Penerapan & $\mathrm{C}$ & $\mathrm{B}$ & $\mathrm{B}$ \\
4. Penutup & $\mathrm{C}$ & $\mathrm{C}$ & $\mathrm{B}$ \\
$\quad$ RATA-RATA & $\mathrm{C}$ & $\mathrm{B}$ & $\mathrm{B}$ \\
\hline
\end{tabular}

\section{Siklus I}

Dari 40 Siswa ternyata banyak siswa yang kurang memperhatikan penjelasan guru atau acuh dalam mengikuti proses belajar mengajar. Hal ini disebabkan karena siswa belum memahami konsep operasi hitung bilangan bulat dan kurang menguasai dalam prasyarat.

Dalam mengikuti pembelajaran pokok bahasan bilangan bulat siswa harus diberi motivasi agar lebih semangat dalam proses belajar mengajar yaitu dengan diberi pertanyaan-pertanyaan yang berhubungan dengan materi yang disampaikan. Bila siswa menjawab dengan benar guru memberi penguatan agar siswa merasa senang.

Dengan melihat hasil prestasi siswa ternyata dari 40 siswa terdapat 23 siswa yang dapat dikategorikan tidak tuntas belajar yaitu yang mendapat nilai kurang dari 60 sedang siswa yang tuntas belajar ada 17 siswa dengan perolehan nilai rata-rata 61,5 dan daya serap 61,5\% terhadap materi pembelajaran.

Dengan melihat tabel pengamatan guru lain dapat dijelaskan bahwa dalam siklus pertama penguasaan guru terhadap materi pelajaran perlu ditingkatkan lagi, perhatian guru kurang merata pada seluruh siswa, belum muncul pertanyaan yang efektif untuk mengarahkan siswa pada pemahaman materi yang sedang disampaikan, masih banyak siswa yang kurang aktif dan sibuk bermain sendiri. Hal itu disebabkan karena kurangnya penguasaan guru terhadap materi.

\section{Siklus II}

Pada siklus ini siswa yang kurang aktif sudah berkurang jika dibandingkan dengan siklus I. Dari hasil prestasi siswa juga terjadi peningkatan kemampuan siswa terhadap menyelesaikan soal, terbukti dari siswa yang tidak tuntas belajar 16 orang, hal ini disebabkan karena motivasi belajar siswa masih kurang. Namun peneliti tetap berusaha untuk selalu memberi motivasi dan bimbingan kepada siswa tersebut di luar jam pelajaran.

Sedangkan siswa yang tuntas belajar ada 24 orang dengan nilai rata- rata pada siklus kedua adalah dengan taraf serap 66,25\%. Berarti ada peningkaan kemampuan siswa dalam menyelesaikan soal operasi hitung bilangan bulat. Sedangkan pengamatan KBM oleh guru lain, kegiatan guru sudah ada peningkatan dibanding siklus I yaitu perhatian guru sudah menyeluruh dan siswa yang pasif mulai termotivasi untuk belajar atau bertanya dengan teman- temannya yang sudah dianggap paham oleh gurunya. Pertanyaanpertanyaan yang mengarahkan siswa pada materi pelajaran sudah cukup produktif sehingga siswa menjadi aktif.

Tindakan-tindakan yang harus dilakukan pada siswa yang mengalami kesulitan adalah siswa diberi bimbingan dan memberikan cara penyelesaian dengan menggunakan garis bilangan untuk bilangan-bilangan yang nilainya kecil. Kemudian dapat ditempuh dengan cara mengumpamakan, jika negatif adalah hutang, sedangkan positif adalah membayar. Dengan cara ini diharapkan siswa akan lebih mudah untuk menyelesaikan penjumlahan bilangan bulat negatif dengan bilangan bulat positif atau bilangan bulat negatif dengan bilangan bulat negatif. Sedangkan untuk pengurangan, siswa diminta terlebih dahulu untuk mengubah kalimat pengurangan tersebut menjadi kalimat penjumlahan dengan invers jumlah (lawan) dari bilangan pengurang. Kemudian mengulang kembali materi yang dianggap sulit oleh siswa dengan sabar dan penuh empati adalah merupakan kata kunci untuk dapat meraih kesuksesan dalam mengajar. Setelah itu siswa diberi soal yang terstruktur dan lebih sederhana. 


\section{Siklus III}

Pada siklus II siswa yang aktif hanya $47 \%$, sedangkan pada siklus III siswa yang aktif telah meningkat menjadi 82,5\% siswa yang acuh telah menurun dibandingkan dengan siklus II. Dari hasil prestasi siswa juga terjadi peningkatan kemampuan siswa dalam menyelesaikan soal, terbukti dari 16 siswa yang tidak tuntas belajar pada siklus II, tinggal 6 orang pada siklus III, hal ini disebabkan karena siswa telah termotivasi untuk belajar dan siswa sudah memahami materi yang disampaikan. Siswa yang tuntas belajar ada 34 orang dengan nilai rata-rata kelas 72,5, pada siklus ketiga daya serap 72,5\%. Berarti ada peningkatan kemampuan siswa dalam menyelesaikan soal pada materi bilangan bulat. Sedangkan pengamatan KBM oleh guru lain, kegiatan guru sudah meningkat dibanding siklus kedua yaitu perhatian guru sudah menyeluruh, penggunaan alat peraga cukup efektif, dan siswa yang belum paham memiliki ketrampilan bertanya yang cukup baik, siswa menjadi lebih aktif bertanya.

Dengan melihat hasil penelitian di kelas VII B SMP Negeri 9 Kota Jambi tersebut di atas dapat dijelaskan bahwa Faktor-faktor yang paling banyak menyebabkan siswa mengalami kesulitan dalam memahami materi yang ada pada pokok bahasan bilangan bulat ini adalah :

a. Siswa tidak paham jika menjumlahkan bilangan bulat negatif dengan bilangan bulat positif.

b. Siswa tidak paham jika mengurangkan bilangan bulat negatif dengan bilangan bulat positif, bilangan bulat negatif dengan bilangan bulat negatif.

c. Siswa tidak paham jika membagi bilangan bulat negatif dengan bilangan bulat positif, bilangan bulat negatif dengan bilangan bulat negatif.

Tindakan-tindakan yang harus dilakukan pada siswa yang mengalami kesulitan adalah siswa diberi bimbingan dan memberikan cara penyelesaian dengan langkah-langkah yang lambat agar siswa tersebut dapat memahami dan dapat mengikuti serta diberikan soal yang terstruktur dan lebih sederhana.

Kriteria Keberhasilan siswa dalam mempelajari materi sub pokok bahasan pembagian adalah :

a. Secara individu bila mereka sudah dapat mencapai nilai 65 atau lebih berarti sudah menyerap materi yang telah diajarkan sebesar $65 \%$ atau lebih dikatakan tuntas belajar.

b. Jumlah siswa dalam kelas dapat menyerap materi $75 \%$ dari jumlah siswa keseluruhan dengan nilai rata rata kelas mencapai lebih dari 75 .

c. Dengan melihat tabel pengamatan oleh guru lain dalam KBM dapat dijelaskan bahwa dalam siklus ketiga penguasaan guru terhadap materi pelajaran sudah baik, tetapi perhatian guru kurang merata di seluruh kelas sehingga ada beberapa siswa yang pasif dan sibuk bermain sendiri. Pada siklus ketiga kegiatan guru dalam KBM sudah cukup baik, khususnya siswa yang belum tuntas belajar untuk memahami materi cukup antusias, siswa mau bertanya tentang kesulitan yang dialaminya. Pada silkus ke III kegiatan guru dalam KBM sudah cukup baik. Perhatiannya sudah merata seluruh kelas dan siswa kelihatan aktif semua.

\section{SIMPULAN}

Hasil penelitian pada siklus I menunjukkan masih banyak siswa yang belum memahami konsep operasi hitung bilangan bulat. Selain itu, masih banyak siswa yang kurang aktif mengikuti pembelajaran. Pada siklus II terlihat siswa sedikit lebih aktif dari sebelummnya. Jumlah siswa yang tuntas dalam pembelajaran pun sudah mengalami peningkatan dari sebelumnya hanya 17 orang, kini menjadi 24 orang. Pada siklus III keaktifan siswa mencapai 82,5\% dengan ketuntasan 88\% dan nilai rata-rata kelas 72,5.

Berdasarkan hasil yang diperoleh pada siklus I, II dan III dapat disimpulkan bahwa penggunaan alat peraga garis bilangan dapat meningkatkan prestasi belajar siswa dalam menyelesaikan soal operasi hitung bilangan bulat.

\section{DAFTAR PUSTAKA}

Cholik, Sugijono, D. Subroto. 2000. Matematika untuk SLTP Kelas 1. Jakarta: Erlangga.

Hariadi, Sugeng dkk. 1993. Perkembangan Peserta Didik. Semarang: IKIP Semarang Press.

Departemen Pendidikan Nasional. 2003. Undang-Undang Republik Indonesia Nomor 20 Tahun 2003 tentang Sistem Pendidikan Nasional. Jakarta:.Depdiknas.

Kuswandi. 2001. Pembelajaran Siswa SLTP. Surakarta: FKIP Universitas Sebelas Maret. 
Sadiman, A. S. 2001. Bunga Rampai Dan Psikologi Pembelajaran. Semarang: WRI (Walisongo Research Institute).

Sugiarto, Isti Hidayah. 2004. Workshop Pendidikan Matematika. Semarang: FPMIPA UNNES.

Walgito, Bimo. 1995. Bimbingan dan Penyuluhan di Sekolah. Yogyakarta: Andi Offset. 